\title{
Multiplex Detection of Criniviruses Associated with Epidemics of a Yellowing Disease of Tomato in Greece
}

C. I. Dovas and N. I. Katis, Plant Pathology Laboratory, Faculty of Agriculture, Aristotle University of Thessaloniki, 54 006, Thessaloniki, Greece; and A. D. Avgelis, National Agricultural Research Foundation, Plant Protection Institute, Plant Virology Laboratory, 71003 Heraklio, Crete, Greece

\begin{abstract}
Dovas, C. I., Katis, N. I., and Avgelis, A. D. 2002. Multiplex detection of criniviruses associated with epidemics of a yellowing disease of tomato in Greece. Plant Dis. 86:1345-1349.

Since 1997, a yellowing disease has been observed in greenhouse tomato (Lycopersicon esculentum). By 2001, the disease was widespread, including open field tomato crops, and in most cases its incidence was 80 to $90 \%$ or even $100 \%$. Epidemics in glasshouses were mainly associated with high populations of the whitefly Trialeurodes vaporariorum and Bemisia tabaci, the major whitefly pests in vegetable crops in Greece. The main leaf symptoms were severe yellowing, rolling, and brittleness. Samples from symptomatic plants were analyzed by polymerase chain reaction (PCR) and shown to be infected with Tomato infectious chlorosis virus (TICV) and Tomato chlorosis virus (ToCV) (family Closteroviridae, genus Crinivirus). TICV was found in 164 of 183 symptomatic samples, while ToCV was less representative (25/183). Sequence comparisons of the amplified 229-bp and 466-bp products revealed 99 and $100 \%$ identity with the reported sequences of TICV and ToCV, respectively. A reverse transcription (RT) multiplex PCR assay using a simple sample preparation procedure was developed to allow rapid, specific, and simultaneous detection of both ToCV and TICV sequences in two steps. The method involves a one-tube RT-PCR step in which the combination of primers amplifies part of the heat shock protein to homologue gene of both ToCV and TICV, followed by a multiplex nested PCR amplification. This is the first report of TICV and ToCV in Greece and, as far as we know, the first report of TICV in Europe.
\end{abstract}

Additional keywords: diagnosis, RT-PCR

In 1997, a low incidence of yellowing symptoms appeared in greenhouse tomato plants in Southern Greece and the island of Crete. By 2001, the distribution and incidence had increased to the majority of tomatoes grown in greenhouses in Greece. Similar symptoms also appeared, although in lower incidence, in open field-grown tomato crops. Yellowing symptoms were obvious in all cultivated tomato hybrids and were initially attributed to nutritional deficiencies. However, the fact that the first symptomatic plants were near greenhouse openings and were followed by rapid and random disease distribution, led us to investigate a viral etiology. Yellowing symptoms differed considerably from those caused by Tomato yellow leaf curl virus (TYLCV-Is) (family Geminiviridae, genus Begomovirus) (2), and from four major endemic viral diseases of tomato crops in

Corresponding author: N. I. Katis

E-mail: katis@agro.auth.gr

The nucleotide sequences reported in this paper have been deposited in EMBL as Accession nos. AJ344212 and AJ344213.

Accepted for publication 22 July 2002.

Publication no. D-2002-1021-02R

(C) 2002 The American Phytopathological Society
Greece: Alfalfa mosaic virus (AMV), Cucumber mosaic virus (CMV), Potato virus $Y$ (PVY), and Tomato spotted wilt virus (TSWV). Symptoms of affected plants appeared to be more similar to those caused by tomato criniviruses (family Closteroviridae) such as Tomato infectious chlorosis virus (TICV) and Tomato chlorosis virus (ToCV) (23). Both viruses were first reported during the last decade in the United States $(6,19)$, and ToCV has been reported to occur in the Mediterranean countries, Portugal (13), Spain (16), and Italy (1).

The aim of the present research was to clarify the etiology and the incidence of the causal agent of the tomato yellows observed. In addition, polymerase chain reaction (PCR)-based detection methods were optimized and developed toward highly sensitive large-scale applications to test tomato leaves for the presence of TICV and $\mathrm{ToCV}$, focusing on sample preparation and multiplex detection of both viruses.

\section{MATERIALS AND METHODS}

Field surveys and samples tested. Fully developed young leaves showing severe yellowing were collected from tomato plants grown in greenhouses or in open fields from five major tomatogrowing areas, i.e., Crete (Kundura, Platanos, Chania, Messara Valley, Ierapetra),
Peloponnesus (Arkadia, Messinia, Ilia, Achaia, Argolida, Lakonia, Poros), Epirous (Preveza), Macedonia (Pella), and the island of Rodos (Fig. 1). In each surveyed crop, the tomato hybrid was recorded, the incidence of yellowing disease was expressed as the percentage of symptomatic plants over 200 randomly selected plants, and samples from three plants showing typical symptoms were collected for mechanical transmission tests and PCR analysis. Samples were maintained at $4^{\circ} \mathrm{C}$ or lyophilized until they were tested or analyzed. The assayed 183 samples included the following tomato hybrids from 49 glasshouses (147 samples) and 12 fields (36 samples): Baya, Belladona, Troya, Iron, 9/84, Noa, 717 Fitro, Preveza, Alma, Jumbo, Naysica, Galli, Carina, Electra, Cortina, Nefeli, Amati, and Vapsa.

Two Italian ToCV-infected tomato samples from Italy were a kind gift from A. M. Vaira (Istituto di Fitovirologica Applicata, Torino, Italy).

Mechanical inoculations. Tissue from affected plants extracted in phosphate buffer, pH 7.0, $(1 \mathrm{~g} / 10 \mathrm{ml})$ was used to sap inoculate a wide range of indicator plants including: Gomphrena globosa, Chenopodium amaranticolor, C. quinoa, Zinnia elegans, Celosia cristata, Cucumis sativus, C. melo, Cucurbita pepo, Ocimum basilicum, Phaseolus aureus, P. vulgaris cv. Bountiful, Vicia faba, Vigna sinensis, Capsicum annuum, Lycopersicon esculentum cv. Noa F1, Nicotiana benthamiana, $N$. clevelandii, N. glutinosa, N. megalosiphon, N. rustica, N. tabacum cv. W.B., Xanthi, Samsun, Petunia hybrida, and Solanum melongena. The test plants were grown and observed in an insect-proof glasshouse (22 $\pm 2^{\circ} \mathrm{C}, 75 \%$ relative humidity).

Sample preparation for PCR. The extraction protocol was a modification of that reported previously $(10,17)$ and consisted of the following steps: tomato petioles were macerated in extraction buffer $(1.59 \mathrm{~g}$ of $\mathrm{Na}_{2} \mathrm{CO}_{3}$ per liter, $2.93 \mathrm{~g}$ of $\mathrm{NaHCO}_{3}$ per liter, $\mathrm{pH}$ 9.6, 6\% PVP-40, 0.5\% bovine serum albumin, and $0.05 \%$ Tween 20 ) at a 1:20 dilution. A small aliquot of this crude extract was centrifuged in $1.5-\mathrm{ml}$ tubes at $5,000 \times g$ for $2 \mathrm{~min}$, and $2 \mu \mathrm{l}$ was transferred into $200 \mu \mathrm{l}$ of GES buffer $(0.1 \mathrm{M}$ glycine- $\mathrm{NaOH}, \mathrm{pH} 9.0,50 \mathrm{mM} \mathrm{NaCl}, 1$ mM EDTA) containing $0.5 \%$ Triton $\mathrm{X}-100$ and $1 \% \beta$-mercaptoethanol. The mixture was then incubated at $94^{\circ} \mathrm{C}$ for $5 \mathrm{~min}$, 
placed on ice, and $1 \mu \mathrm{l}$ was added to $24 \mu \mathrm{l}$ of reverse transcription (RT)-PCR reaction mixture.

Oligonucleotides. Primers used in this study are presented in Table 1 . In the initial amplification, a pair of degenerate primers (HS-11 and HS-12) that can amplify both ToCV and TICV genomes were used. Both primers were designed based on the primer sequences reported previously (16), and they were derived from highly conserved regions of the heat shock protein (HSP) 70 homologue genes reported for these viruses (GenBank accession numbers: AF024630, AF215817, AF215818, AF233435, AF234029, U67449). Sequence alignment was performed using the program CLUSTAL V. Two pairs of specific primers, one for each virus (TIC-3/TIC-4 and ToC-5/ToC-6), were designed for use in nested PCR. The criteria used for the de- sign of each primer pair were the relative position within the target sequence, specific detection of each virus, range of sizes of the amplicons produced for multiplex detection, similarity of reaction kinetics, and a higher annealing temperature than primers HS-11 and HS-12. Since only one sequence fragment of HSP70 homologue gene has been reported for TICV, more sequence information was needed for sequence comparison and selection of primer TIC-4. For this reason, total RNA was extracted from two TICV-infected tomato samples originating from Crete and Preveza, respectively (15). Two microliters of RNA extract was used in one-step RTPCR using the HS-11/HS-12 primer pair, and 587-bp PCR products were sequenced using primer HS-11 according to the conditions described in the "PCR product sequencing" paragraph.

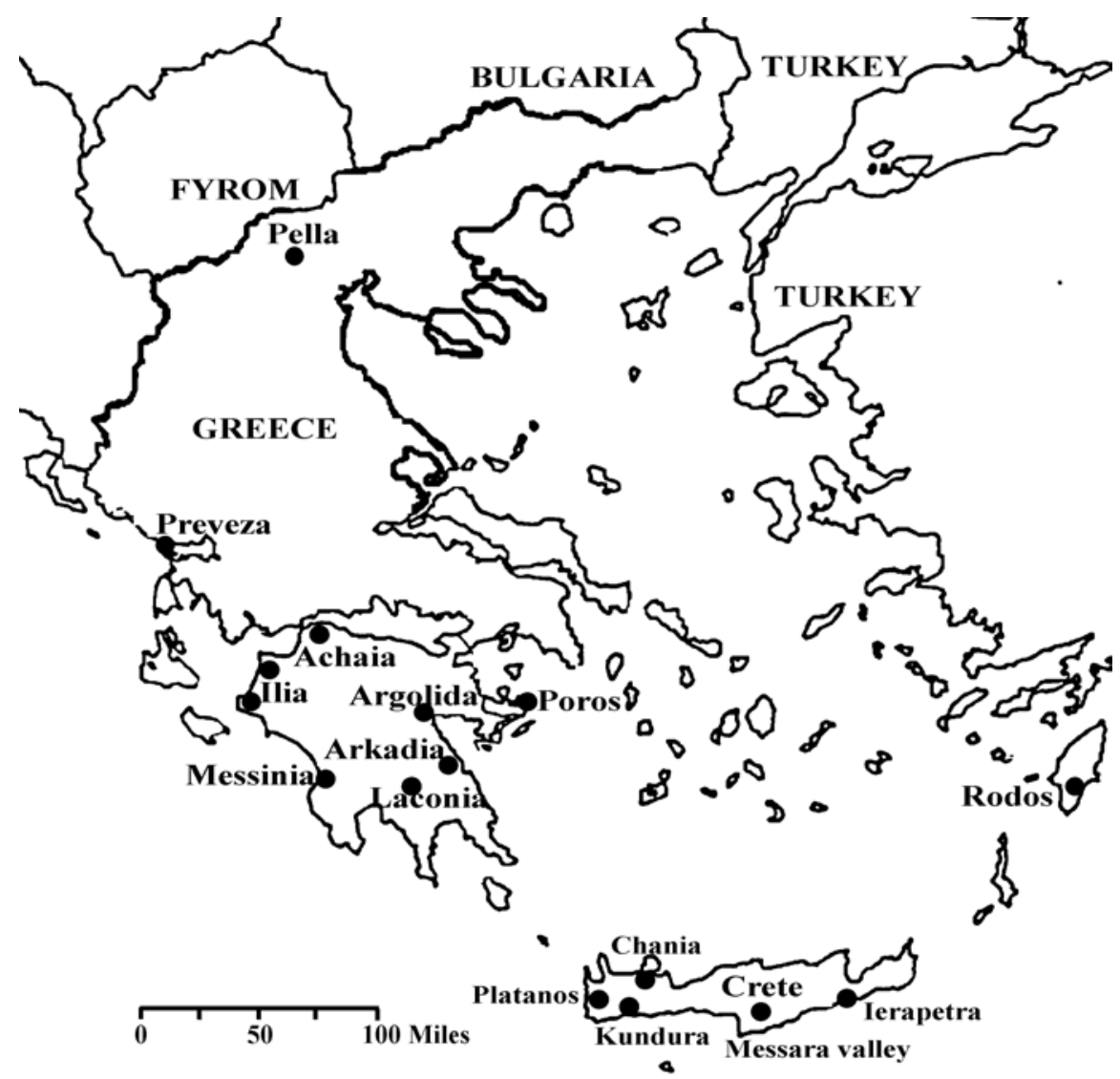

Fig. 1. Map of Greece. Black circles show areas where tomato samples with yellowing symptoms were collected for the present study.

Table 1. Primer pairs used for the detection of Tomato infectious chlorosis virus (TICV) and Tomato chlorosis virus (ToCV), and respective amplicons produced by reverse transcription-polymerase chain reaction (RT-PCR)

\begin{tabular}{|c|c|c|c|c|}
\hline Name & Sequence & $\begin{array}{c}\text { Virus } \\
\text { detected }\end{array}$ & Assay & $\begin{array}{c}\text { Amplicon } \\
\text { size }\end{array}$ \\
\hline HS-11 & $5^{\prime}-\mathrm{GG}(\mathrm{G} / \mathrm{T}) \mathrm{TT}(\mathrm{A} / \mathrm{G}) \mathrm{GA}(\mathrm{G} / \mathrm{T}) \mathrm{TT}(\mathrm{C} / \mathrm{T}) \mathrm{GGTACTAC}-3^{\prime}$ & ToCV, & One step & $587 \mathrm{bp}$ \\
\hline HS-12 & 5'-CC(G/T)CCACCAAA(A/G)TCGTA-3' & TICV & RT-PCR & \\
\hline TIC-3 & 5'-GGGTTAGAGTTCGGTACTACTTTCAGT-3' & & Nested- & \\
\hline TIC-4 & 5'-CGTCGAAAGATTTCTCATCGACT-3' & TICV & PCR & $223 \mathrm{bp}$ \\
\hline ToC-5 & 5'-GGTTTGGATTTTGGTACTACATTCAGT-3' & ToCV & Nested- & $463 \mathrm{bn}$ \\
\hline ToC- 6 & 5'-AAACTGCCTGCATGAAAAGTCTC-3' & ToC $\mathrm{V}$ & PCR & 463 bp \\
\hline
\end{tabular}

First round PCR amplification. The 25- $\mu$ l reaction mixture contained: $10 \mathrm{mM}$ Tris- $\mathrm{HCl}(\mathrm{pH} 8.8), 50 \mathrm{mM} \mathrm{KCl}, 1.5 \mathrm{mM}$ $\mathrm{MgCl}_{2}, 0.1 \%$ Triton $\mathrm{X}-100,0.25 \mathrm{mM}$ of each deoxyribonucleoside triphosphate (dNTP), $5.0 \mathrm{mM}$ DTT, $0.5 \mu \mathrm{g}$ purified BSA (New England Biolabs, Beverly, MA), 12 units RNASEOUT (Life Technologies, Inc., Gaithersburg, MD), 1.0 unit Avian Myeloblastosis Virus Reverse Transcriptase (Finnzymes Oy, Espoo, Finland), and 0.6 units Dynazyme II DNA Polymerase (Finnzymes), and a final concentration of $1 \mu \mathrm{M}$ for each primer (HS-11 and HS-12). The cycling profile was as follows: first step at $42^{\circ} \mathrm{C}$ for $60 \mathrm{~min}$, second step at $50^{\circ} \mathrm{C}$ for $2 \mathrm{~min}$, third step at $94^{\circ} \mathrm{C}$ for $5 \mathrm{~min}, 35$ cycles segmented in step 1: $30 \mathrm{~s}$ at $95^{\circ} \mathrm{C}$, step 2: $30 \mathrm{~s}$ at $43^{\circ} \mathrm{C}$, step 3: $15 \mathrm{~s}$ at $72^{\circ} \mathrm{C}$, followed by a final extension step at $72^{\circ} \mathrm{C}$ for $2 \mathrm{~min}$. Amplifications were carried out in a GeneAmp 2400 thermal Cycler (Perkin Elmer, Norwalk, CT) utilizing thin-walled reaction tubes.

Nested PCR amplification. Part of the collected samples, consisting of 90 symptomatic tomato samples from 11 different locations in Greece (Table 2) and two ToCV-infected samples from Italy, were used to test the performance (polyvalence and specificity) of the primers designed in this study. Twenty microliter nested PCR reactions were performed. The reaction mixture contained $20 \mathrm{mM}$ Tris- $\mathrm{HCl}(\mathrm{pH}$ 8.8), $50 \mathrm{mM} \mathrm{KCl}, 1.5 \mathrm{mM} \mathrm{MgCl}_{2}, 0.2 \mathrm{mM}$ of each dNTP, and 0.5 unit Taq DNA Polymerase (Life Technologies). A final concentration of $0.2 \mu \mathrm{M}$ for each primer pair was used for the detection of TICV (TIC3/TIC-4) or ToCV (ToC-5/ToC-6). The cycling profile consisted of a first denaturizing step at $95^{\circ} \mathrm{C}$ for $1 \mathrm{~min}, 40$ cycles segmented in $20 \mathrm{~s}$ at $95^{\circ} \mathrm{C}, 15 \mathrm{~s}$ at $60^{\circ} \mathrm{C}$, and $10 \mathrm{~s}$ at $72^{\circ} \mathrm{C}$, followed by one final extension step at $72^{\circ} \mathrm{C}$ for $2 \mathrm{~min}$. The reaction products were analyzed by electrophoresis in $1.5 \%$ agarose gels in TAE buffer (1×0.04 M Tris-acetate, 0.001 M EDTA), stained with ethidium bromide, and visualized under UV light.

Sequencing of PCR products. Specificity of both nested primer pairs was confirmed by direct sequencing the PCR products. Two isolates of each TICV and ToCV were amplified by RT-PCR with primer pairs HS-11/HS-12 and subsequently using the nested-PCR conditions described above for single-virus detection with primer pairs TIC-3/TIC-4 and ToC-5/ToC-6. NestedPCR products were purified with QIAquick PCR Purification Kit (Qiagen, Chatsworth, CA), and both strands were sequenced with an ABI Prism 3700 DNA Analyzer, using ABI PRISM BigDye Terminators v3.0 Cycle Sequencing Kit (Applied Biosystems, Foster City, CA).

Multiplex PCR. All collected samples were tested by multiplex PCR with a protocol identical to the single-virus assays described previously except for modifica- 
tions in primer concentrations used in nested PCR. A titration of primer pairs was necessary for equal amplification of both amplicons in doubly infected samples. A final concentration of $0.2 \mu \mathrm{M}$ for each of TIC-3 and TIC-4 and $0.4 \mu \mathrm{M}$ for each of ToC-5 and ToC- 6 was selected for routine use.

\section{RESULTS AND DISCUSSION}

Tomatoes are one of the most important vegetable crops in Greece, with the majority of tomatoes used for fresh consumption obtained from open fields (19,100 ha) and a small proportion of early tomatoes from the greenhouse $(2,600$ ha). About 24,100 ha are field cultivated for canned tomatoes. The last few years, a yellowing disease appeared to be endemic in the greenhouse tomatoes, usually in high incidence, and more rarely in the open field. In 2001, a large-scale survey found that many cultivated tomato hybrids had similar yellowing leaf symptoms. The main symptoms were irregular chlorotic areas on the leaves, which gradually progressed into interveinal chlorosis, rolling, and brittleness. Symptoms initially appeared in the lower, but also in the middle leaves, and eventually on the upper part of the plant. Affected plants produced smaller fruits, which ripened later, although without any symptoms. These symptoms were similar to those caused by criniviruses such as TICV and ToCV, both of which first appeared in the United States $(21,22)$. Initially, symptomatic plants were scattered in the affected crops, and the initial foci were usually in the greenhouse openings or at the outer lines of the open field crops. Disease incidence increased gradually, and by the end of the growing season, almost all plants were affected both in the field and in the greenhouse.

We were unable to reproduce yellowing symptoms by mechanical inoculation onto indicator tomato plants (hybrid Noa) using sap from affected tomato plants. However, in a few cases, isolates of CMV, PVY, and TSWV were mechanically isolated and detected by serological identification.

To investigate the etiology of the yellowing disease of tomato and the implication of the TICV and ToCV criniviruses, we designed specific primers for their reliable detection. Additionally, a multiplex nested PCR was developed for large-scale detection applications. A fraction (90 samples) of the symptomatic tomato samples collected from 11 different locations in Greece and two ToCV-infected samples from Italy were tested by uniplex nested PCR. Ten and 84 samples were found infected by ToCV and TICV, respectively (four samples were infected by both viruses). In all cases, nested PCR yielded the amplification products expected for each virus. Direct sequencing of four nested PCR products amplified from TICV- and ToCV-infected tomato samples revealed 99 and $100 \%$ identity to the corresponding HSP70 homologue region of ToCV (EMBL no. AF024630, AF233435, AF215817, AF215818, and AF234029) and TICV (EMBL no. U67449), respectively, confirming their viral origin. Two sequences were used for the selection of primer TIC-4 and deposited in EMBL/GenBank database (Accession numbers: AJ344212 and AJ344213). Multiplex PCR successfully detected both viruses in all 90 samples infected either by a single virus or both viruses simultaneously, and all results were in agreement with uniplex PCR tests performed previously. From all of the 183 collected samples tested by multiplex PCR, 25 and 164 samples were infected by ToCV and TICV, respectively, and six samples were infected by both viruses. Figure 2 presents selected nested multiplex PCR results of TICV and ToCV detection from 13 samples from different geographic regions.

This large-scale survey clearly showed the close association of TICV and ToCV criniviruses with the yellowing disease of tomatoes in Greece. All tested samples from plants showing the yellowing disease were positive to one or both criniviruses. About $70 \%$ of the inspected crops showed high incidence of the disease with over $40 \%$ of symptomatic plants (Table 2). TICV, a Trialeurodes vaporariorum-borne

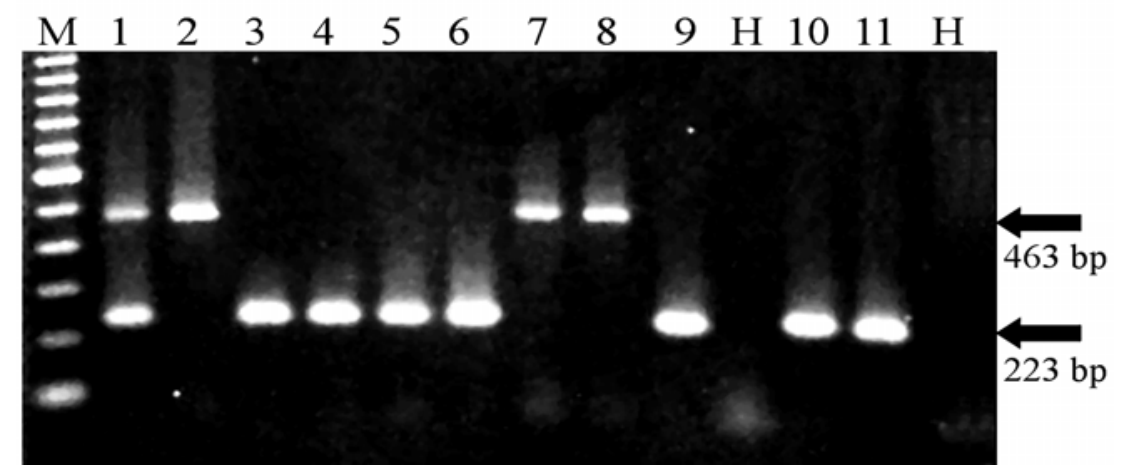

Fig. 2. Partial results from multiplex nested polymerase chain reaction (PCR) amplification of field grown and greenhouse tomato plants naturally infected with Tomato infectious chlorosis virus (TICV) and Tomato chlorosis virus (ToCV) (lanes 1 to 11). Sample 1 is doubly infected by ToCV and TICV. H, healthy controls; M, 100-bp DNA ladder.

Table 2. Incidence of the yellowing disease in greenhouse and open field grown tomato crops surveyed during 2001 in Greece, and associated criniviruses: Tomato infectious chlorosis virus (TICV) and Tomato chlorosis virus (ToCV)

\begin{tabular}{|c|c|c|c|c|c|c|c|c|}
\hline \multirow[b]{2}{*}{ Site } & \multirow{2}{*}{$\begin{array}{l}\text { No. of fields } \\
\text { inspected }\end{array}$} & \multicolumn{5}{|c|}{ No. of fields with incidence level $(\%)^{\mathrm{a}}$} & \multirow{2}{*}{$\begin{array}{l}\text { Fields infected by } \\
\text { TICV/ToCV }\end{array}$} & \multirow[b]{2}{*}{ Cultivar } \\
\hline & & $<\mathbf{2 0}$ & $20-40$ & $40-60$ & $60-80$ & $>\mathbf{8 0}$ & & \\
\hline Rhodos & 3 & & 1 & 1 & & 1 & $0 / 3$ & Belladonna, Troya \\
\hline Crete & 12 & $\ldots$ & 1 & 2 & 3 & 6 & $9 / 4$ & $\begin{array}{l}\text { Baya, Belladonna, Iron } \\
\text { Noa, 9/84, } 717 \text { Fitro }\end{array}$ \\
\hline Arkadia & 13 & $\ldots$ & 4 & 1 & 1 & 7 & $13 / 0$ & $\begin{array}{l}\text { Preveza, Alma, Jumbo } \\
\text { Naysika, Galli, Arion }\end{array}$ \\
\hline Messinia & 4 & $\ldots$ & 2 & 2 & $\ldots$ & $\ldots$ & $4 / 0$ & Baya \\
\hline Ilia & 9 & 1 & $\ldots$ & $\ldots$ & $\ldots$ & 8 & $9 / 0$ & $\begin{array}{l}\text { Belladonna, Iron, Noa, } \\
\text { Cortina, Electra }\end{array}$ \\
\hline Achaia & 3 & 1 & $\ldots$ & 1 & $\ldots$ & 1 & $3 / 0$ & Belladonna, Nefeli Cortina \\
\hline Argolida & 1 & $\ldots$ & $\ldots$ & 1 & $\ldots$ & $\ldots$ & $1 / 0$ & Unknown \\
\hline Laconia & 1 & $\ldots$ & $\ldots$ & 1 & $\ldots$ & $\ldots$ & $1 / 0$ & Unknown \\
\hline Poros & 3 & 1 & 2 & $\ldots$ & $\ldots$ & $\ldots$ & $2 / 2$ & Baya \\
\hline Preveza & 11 & 2 & 4 & 3 & 1 & 1 & $11 / 0$ & $\begin{array}{l}\text { Jambo, Galli, Baya, Amati, } \\
\text { Vapsa, Noa }\end{array}$ \\
\hline Pella & 1 & & & 1 & & & $0 / 1$ & Unknown \\
\hline Total & 61 & 5 & 14 & 13 & 5 & 24 & $53 / 10$ & \\
\hline
\end{tabular}

${ }^{a}$ Incidence of symptomatic plants exhibiting the yellowing disease of 200 plants evaluated; ... indicates that no field with this incidence level was observed. 
virus, has been identified in the majority of the sampling areas (53 fields out of 61 tested, about $87 \%$ ), whereas ToCV, a virus transmitted by $T$. vaporariorum, Bemisia tabaci, and T. abutilonea, was only present in 10 fields, in Rhodos, Crete, Poros, and Pella (Macedonia), and it was found in mixed infections with TICV in two fields in Crete and Poros (Attica). Interestingly, ToCV was not detected in any of the 12 open field tomato crops (data not shown) showing yellowing symptoms where TICV was always present. Although the impact of criniviruses, either alone or in mixed infection with other viruses (TYLCV-Is, TSWV, CMV), on tomato production has not been determined yet, it seems that at least under our conditions, favoring their incidence, they will be a limiting factor in tomato production. Crinivirus epidemics were always associated with crops heavily infested by both $T$. vaporariorum and $T$. tabaci. In Greece, although there are no systematic studies on their incidence, $B$. tabaci is considered to be more frequent in open field crops and in the greenhouses during late summer to early autumn. On the other hand, T. vaporariorum is more abundant in greenhouse crops during winter and spring. However, differences in their distribution may occur in southern Greece, including islands, and northern Greece due to different environmental conditions. The other vector species of TICV, T. abutiloneus, so far has not been recorded in Greece (14). On the contrary, in countries of the Mediterranean basin such as Spain (16), Portugal (13), and Italy (1), where B. tabaci was the predominant whitefly present, ToCV was the only crinivirus present, and it is considered the causal agent of the tomato yellowing disease.

TICV and ToCV were identified in more than 18 tomato hybrids cultivated in Greece, and no differences could be observed in symptomatology and disease incidence. A similar situation was observed among the cultivated tomato cultivars in southern Spain (16).

Whiteflies, mainly B. tabaci and T. vaporariorum, have become major crop pests all over the world, particularly in tropical and subtropical areas $(3,5)$. Both species have become serious pests in Mediterranean countries; therefore, criniviruses together with TYLCV might now represent major threats to this important crop. During the dry and warm season, the tobacco whitefly, B. tabaci, seems to be the major pest in most of the Mediterranean countries, resulting in great yield losses both by direct damage and the transmission of TYLCV and ToCV in tomato crops $(13,16)$.

The yellowing disease of tomato represents a new threat to tomato production all over Greece. Initially, yellowing symptoms were attributed to mineral deficiencies and possible virus implication was overlooked.
Soon thereafter, as the first "nest" of heavily affected greenhouses was noticed in the Koundura area (southwestern Crete) in late 2000 , investigations were directed to isolate and identify the viruses implicated. During the 1990s, aphid-borne viruses such as AMV, CMV, and PVY and the thripsborne TSWV appeared to be the most widespread tomato viruses in Greece $(4,8,9,20)$. Although symptoms similar to those caused by TYLCV were first observed sporadically in Crete at the beginning of the 1990s, it was only in 2000 and 2001 that epidemics appeared in southern Crete. Soon thereafter, the disease also appeared in areas of continental Greece such as Attiki, Preveza, and the southern Peloponnese (2; A. D. Avgelis, unpublished data), and recently an epidemic has been observed on the island of Rodos (E. Papadopoulou, C. I. Dovas, N. I. Katis, unpublished data). This survey (extended in all the important tomato producing areas) confirmed the spread and occurrence of a new viral tomato disease. Two criniviruses were implicated with the disease: TICV and ToCV. This is the first report of these viruses in Greece.

During the last 10 years, yellowing symptoms were also widespread in cucumber and melon in glasshouses and open field crops all over Greece. A close relationship was found between the presence of criniviruses and yellowing symptoms. Initially, Beet pseudo-yellows virus (BPYV) was identified as the only causal agent of the disease in the western Pelloponnese (12) and on the island of Crete (18). However, in a more extended survey, BPYV was found to occur in all areas where yellowing symptoms were observed, but Cucurbit yellowing stunting disorder virus (CYSDV) was also isolated from affected cucumber and melon crops in the islands of Rhodos, Poros, and in the area of Leonidio in the mainland (eastern Peloponnesse) (I. Bourbourakas and N. I. Katis, unpublished data). BPYV is transmitted by T. vaporariorum (6), whereas CYSDV is transmitted by B. tabaci (22). The data concerning the criniviruses observed in tomato and cucurbit crops in Greece indicate that $T$. vaporariorum is probably the most prevalent whitefly. However, largescale surveys of whiteflies throughout the country will answer this question.

Until now, specific detection of tomato criniviruses such as TICV (11) and simultaneous detection of both TICV and ToCV (16) were based on RT-PCR involving double tube PCR formats and total RNA extracts as templates. Primers were designed for a comprehensive detection of ToCV and TICV by RT-PCR based methods. A previously developed simple sample preparation (17) alleviating the need for laborious preparation of purified RNA was coupled to a one-tube RT-PCR protocol using a pair of degenerate primers for the amplification of part of the HSP region of both viruses (7). In this study, to increase detection sensitivity and simultaneous differentiation of ToCV and TICV, a multiplex nested PCR assay followed, utilizing primers designed to anneal into the amplification product from the first reaction. Differential detection of each virus was made possible by the size of its respective PCR product. Sample preparation for PCR testing has proven to be difficult, due to the effect of putative PCR-inhibitors of plant origin. Total nucleic acid extraction is costly and not practical for routine diagnosis when analysis of many samples is required. The simple sample preparation method combined with one-tube RT-PCR protocol allows simple, fast, and costeffective analysis of a large number of samples. Application of nested PCR compensated for the potential decrease in sensitivity due to the high dilutions required during sample preparation. In addition, the use of two pairs of specific primers in nested PCR producing two different-sized amplicons allows specific detection and differentiation of both viruses. Multiplex PCR methods are less labor demanding and more economical than single PCR methods. Our experiments confirmed the specificity of primer pairs TIC-3, -4 and ToC-5, -6 for their respective target viruses in both single-virus and multiplex PCR assays. Based on this finding, the multiplex system was used for testing of all collected samples. The primers amplified successfully more than 164 isolates of TICV and 25 isolates of ToCV from different geographic regions in Greece along with two ToCV isolates from Italy. The nested PCR described here for multiplex detection of both viruses could be useful for study of the tomato yellowing etiology and their epidemiology since large numbers of samples can be tested. However, thorough examination of the primers polyvalence should be conducted by testing more virus isolates to evaluate the reported assay for worldwide monitoring distribution and host range of both viruses. To our knowledge, this is the first report of a multiplex nested PCR assay that can reliably detect and discriminate two criniviruses such as TICV and ToCV.

\section{ACKNOWLEDGMENTS}

The authors thank P. E. Kyriakopoulou (Agricultural University of Athens, Plant Pathology Lab.), Crop Protection specialist Kosmas Papachristou, (Agriculturist, Office of Crop Protection, Ministry of Agriculture, Region of Preveza, Epirous, Greece), Fanis Papanikolopoulos (Agriplan, Varda Ilias), Maria Hepaki (Rodos) and A. M. Vaira (Istituto di Fitovirologica Applicata, Torino, Italy) for providing ToCV-infected tomato material.

\section{LITERATURE CITED}

1. Accotto, G. P., Vaira, A. M., Vecchiati, M. Finetti Sialer, M. M., Gallitelli, D., and Davino, M. 2001. First report of Tomato chlorosis virus in Italy. Plant Dis. 85:1208.

2. Avgelis, A. D., Roditakis, N., Dovas, C. I., Katis, N. I., Varveri, C., Vassilakos, N., and 
Bem, F. 2001. First Report of Tomato yellow leaf curl virus on Tomato Crops in Greece. Plant Dis. 85:678.

3. Brown, J. K. 1994. Current status of Bemisia tabaci as a plant pest and virus vector in agroecosystems worldwide. FAO Plant Prot. Bull. 42:3-33.

4. Chatzivassiliou, E., Livieratos, I. C., Katis, N., Avgelis, A., and Lykouressis, D. 1996. Occurrence of tomato spotted wilt virus in vegetables and ornamentals in Greece. Acta Hortic. 431:44-50.

5. Cohen, S., Duffus, J. E., and Liu, H. Y. 1992. A new Bemisia tabaci biotype in the southwestern United States and its role in silverleaf of squash and transmission of lettuce infectious yellows virus. Phytopathology 82:86-90.

6. Duffus, J. E., Liu, H.-Y., and Wisler, G. C. 1996. Tomato infectious chlorosis virus. A new clostero-like virus transmitted by Trialeyrodes vaporariorum. Eur. J. Plant Pathol. 102:219-226.

7. Karasev, A. V., Nikolaeva, O. V., Koonin, E. V., Gumpf, D. J., and Garnsey, S. M. 1994. Screening of the closterovirus genome by degenerate primer-mediated polymerase chain reaction. J. Gen. Virol. 75:1415-1422.

8. Katis, N., and Avgelis, A. 1991. Infection of tomato fruits by Cucumber mosaic virus (CMV). Geotech. Issues 4:17-22 (In Greek).

9. Kyriakopoulou, P. E., Bem, F., and Varveri, C. 1991. Tomato shrinkage and tomato fruit toughness, two new diseases in Greece, probably related to cucumber mosaic virus. Ann. Inst.
Phytopathol. Benaki, (N.S.) 16:251-256.

10. La Notte, P., Minafra, A., and Saldarelli, P. 1997. A spot PCR technique for the detection of phloem-limited grapevine viruses. J. Virol. Methods 66:103-108.

11. Li, R. H., Wisler, G. C., Liu, H.-Y., and Duffus, J. E. 1998. Comparison of diagnostic techniques for detecting tomato infectious chlorosis virus. Plant Dis. 82:84-88.

12. Livieratos, I., Katis, N., and Coutts, R. H. A. 1998. Differentiation between cucurbit yellow stunting disorder virus and beet pseudoyellows virus by a reverse transcriptionpolymerase chain reaction assay. Plant Pathol. 47:362-369.

13. Louro, D., Accotto, G. P., and Vaira, A. M. 2000. Occurrence and diagnosis of tomato chlorosis virus in Portugal. Eur. J. Plant Pathol. 106:589-592.

14. Martin, J. H., Mifsud, D., and Rapisarda, C. 2000. The whiteflies (Hemiptera: Aleyrodidae) of Europe and the Mediterranean basin. Bull. Entomol. Res. 90:407-448.

15. Nassuth, A., Pollari, E., Helmeczy, K., Stewart, S., and Kofalvi, S. A. 2000. Improved RNA extraction and one-tube RT-PCR assay for simultaneous detection of control plant RNA plus several viruses in plant extracts. J. Virol. Methods 90:37-49.

16. Navas-Castillo, J., Camero, R., Bueno, M., and Moriones, E. 2000. Severe yellowing outbreaks in tomato in Spain associated with infections of Tomato chlorosis virus. Plant Dis. 84:835-837.
17. Rowhani, A., Biardi, L., Johnson, R., Saldarelli, P., Zhang, Y. P., Chin, J., and Green, M. 2000 Simplified sample preparation method and onetube RT-PCR for grapevine viruses. 13th ICVG Conf., Adelaide. Page 148.

18. Rubio, L., Soong, J., Kao, J., and Falk, B. W. 1999. Geographic distribution and molecular variation of isolates of the three whiteflyborne closteroviruses of cucurbits: Lettuce infectious yellows virus, Cucurbit yellow stunting disorder virus, and Beet pseudo-yellows virus. Phytopathology 89:707-711.

19. Simone, G. W., Hochmuth, R. C., Wisler, G. C., Duffus, J. E., Liu, H.-Y., and Li, R. H 1996. A new whitefly-vectored closterovirus of tomato in Florida. Tom. Inst. Proc. 71-74.

20. Vovlas, C., and Avgelis, A. D. 1994. Tomato spotted wilt virus (TSWV) in tomato crops in Crete (Greece). Inform. Fitopatol. 1:55-56.

21. Wisler, G. C., Duffus, J. E., and Liu, H.-Y. 1999. Expansion of tomato-infecting Criniviruses into new areas. Page 70 in: Plant Virus Epidemiology: Current Status and Future Prospects. Abstracts VII Int. Plant Virus Epidemiology Symposium, Almeria, Spain.

22. Wisler, G. C., Duffus, J. E., Liu, H.-Y., and Li, R. H. 1998. Ecology and epidemiology of whitefly-transmitted closteroviruses. Plant Dis. 82:270-279.

23. Wisler, G. C., Li, R. H., Liu, H.-Y., Lowry, D. S., and Duffus, J. E. 1998. Tomato chlorosis virus: A new whitefly-transmitted, phloemlimited, bipartite closterovirus of tomato. Phytopathology 88:402-409.

\section{ERRATUM / Volume 86, Number 12, 2002}

In our article "Multiplex Detection of Criniviruses Associated with Epidemics of a Yellowing Disease of Tomato in Greece" by C. I. Dovas, N. I. Katis, and A. D. Avgelis, pages 1345-1349, we claimed that during that work there was the first report of Tomato infectious chlorosis virus (TICV) in Europe. However, TICV had already been found in Italy (Wisler et al., 1998). In addition, during 2002, two more papers reporting the presence of TICV in Italy (Vaira et al., 2002) and Spain (Font et al., 2002) appeared.

\section{References}

Font, M. I., Martinez-Culebras, P., Jorda, M. C., Louro, D., Vaira, A. M., and Accotto, G. P. 2002. First report of Tomato infectious chlorosis virus in Spain. Plant Dis. 86:696.

Vaira, A. M., Accotto, G. P., Vecchiati, M., and Bragaloni, M. 2002. Tomato infectious chlorosis virus causes leaf yellowing and reddening of tomato in Italy. Phytoparasitica 30:290-294.

Wisler, G. C., Duffus, J. E., Liu, H.-Y., and Li, R. H. 1998. Ecology and epidemiology of whitefly-transmitted closteroviruses. Plant Dis. 82:270-279. 